\title{
Effects of atmospheric circulation on summertime precipitation variability and glacier mass balance over the Tuyuksu Glacier in Tianshan Mountains, Kazakhstan
}

\author{
Nina K KONONOVA ${ }^{1}$, Nina V PIMANKINA ${ }^{2}$, Lyudmila A YERISKOVSKAYA ${ }^{2}$, LI Jing ${ }^{3}$, BAO Weijia ${ }^{3}$, \\ LIU Shiyin ${ }^{3 *}$ \\ ${ }^{1}$ Institute of Geography, Russian Academy of Sciences, Moscow 117312, Russia; \\ ${ }^{2}$ Institute of Geography, Ministry of Education and Science, Almaty 050010, Kazakhstan; \\ ${ }^{3}$ State Key Laboratory of Cryospheric Sciences, Cold and Arid Regions Environmental and Engineering Research Institute, \\ Chinese Academy of Sciences, Lanzhou 730000, China
}

\begin{abstract}
The amount and the form of precipitation have significant effects on glacier mass balances in high altitude mountain areas by controlling the accumulation, the ablation and the energy balance of a glacier through impact on the surface albedo. The liquid precipitation has negative effects on glacier accumulation and may increase the ablation of surface ice through the heat input for melting. The timing and the forms of precipitation over glacierized regions depend on the weather processes both locally and regionally. Early studies showed that regional to large-scale atmospheric circulation processes play a key role in affecting the precipitation events over glaciers. This paper analyzed the relationship between the inter-annual variability of the summertime precipitation over the Tuyuksu Glacier and the atmospheric circulation types, which related to various atmospheric circulation types in the Northern Hemisphere. Results indicated that the decrease in the duration of zonal processes and the increase in the meridional northern processes were observed in the last decade. The total summer precipitation associated with these processes also increased along with an increase of summertime solid precipitation. Although the decadal fluctuation of glaciological parameters were found in dependent of the above large-scale atmospheric circulation processes, global warming was a dominant factor leading to the mass loss in the recent decades under the background of the increase in precipitation over the Tuyuksu Glacier.
\end{abstract}

Keywords: atmospheric circulation; precipitation; glacier; mass balance

Citation: Nina K KONONOVA, Nina V PIMANKINA, Lyudmila A YERISKOVSKAYA, LI Jing, BAO Weijia, LIU Shiyin. 2015. Effects of atmospheric circulation on summertime precipitation variability and glacier mass balance over the Tuyuksu Glacier in Tianshan Mountains, Kazakhstan. Journal of Arid Land, 7(5): 687-695. doi: 10.1007/s40333-015-0083-3

Glacier regime is largely determined by large-scale atmospheric circulation processes. The accumulation and the ablation of glaciers depend on weather conditions, primarily on precipitation and air temperature. Intra-annual distribution of precipitation falling over the Zailiiskiy Alatau range and adjacent territories depends on both the general circulation pattern of atmosphere and local physiographic conditions, while multiyear variations of precipitation depend on the features of atmospheric circulation.

The atmospheric circulation types and assessment methods were established by Vangengeim (1952), Baidal (1964) and Girs (1974). Vangengeim (1952), Denisova et al. (1986) and Golovkova et al. (1986) analyzed the impact of atmospheric processes on the fluctuations of the Tuyuksu Glacier using the classification method and found low correlations among the glacier mass balance, equilibrium line altitude

*Corresponding author: LIU Shiyin (E-mail: liusy@1zb.ac.cn)

Received 2014-11-04; revised 2015-02-23; accepted 2015-03-02

(C) Xinjiang Institute of Ecology and Geography, Chinese Academy of Sciences, Science Press and Springer-Verlag Berlin Heidelberg 2015 
and the atmospheric circulation patterns. The classification of circulation processes (Dzerdzeevskii, 1962) was used to evaluate the influence of synoptic processes on the precipitation and the variations of mass balance on the Tuyuksu Glacier. The elementary circulation mechanisms (ECMs), a term to describe the timing and types of dominant atmospheric circulations in a year in the North Hemisphere and each type of the atmospheric circulation controls a certain type of weather process as detailed in section 3 , were attributed to the fluctuation of mass balances of the glacier (Yeriskovskaya and Pimankina, 2009; Pimankina et al., 2013).

The timing and the amount of snow falling in summer affect the status and the range of the glacier through participating the melting process of the snow and ice, which could change the albedo of the glacier surface. Liquid precipitation falling on snow cover of a glacier can accelerate the snow melting when the snow is at the melting point. Therefore the increase in the amount of liquid precipitation in summer plays a significant role in the melting of snow and ice, so does the mass balance of a glacier (Cherkasov and Yeriskovskaya, 1997).

Long-term variation of precipitation can be a particular impact factor on the dynamics of glaciers through influencing glacier mass balances, for example the accumulation due to snowfall and ablation due to rainfall. The purpose of this study was to explore the relationship between the summertime precipitation and the atmospheric circulation patterns (Dzerdzeevskii 1962) at the Tuyuksu Glacier based on the data available over the decades from the meteorological and glaciological observation stations in the region.

\section{Study area}

The climate of southeast Kazakhstan is determined by its location in the center of Asia-Europe Continent with the impact of water-bearing westerlies, Siberian anti-cyclones and southern cyclones. West wind controls the glacierized areas at the altitude above 3,300 $\mathrm{m}$ asl zone. The annual temperature was $7-9^{\circ} \mathrm{C}$ in low-altitudinal zone $(<1,000 \mathrm{~m}$ asl $)$ and -2 to $-1.5^{\circ} \mathrm{C}$ at high altitude zone $(>3,000 \mathrm{~m}$ asl). Annual precipitation increased from $400-700 \mathrm{~mm}$ at the foothills below $1,000 \mathrm{~m}$ asl to $900-1,200 \mathrm{~mm}$ at the high-mountains above 3,000 $\mathrm{m}$ asl.

The Zailiiskiy Alatau Mountains, where Tuyuksu Glacier is located, are influenced by four dominant cyclone trajectories. The major part of the summer precipitation falling in June to August was under the control of cyclones from Iran to the Polar front. The main directions of their tracks are from southwest towards northeast. The prevalence of meridional circulation in these incursions is favorable to the glacier accumulation by increasing the mass gain or decreasing the mass loss. The number of days under the control of the circulation (named 13s as described below) increased from the 1980s to the beginning of the 2000s, and then decreased (Kononova, 2009). Detailed discussions were given in the following sections.

There are 11 glaciers in the Little Almatinka River Basin on the northern slope of Tianshan Mountains, which experienced retreat over the last decades (Fig. 1) (Hagg et al., 2007). Tsentralniy (Central) Tuyuksu Glacier $\left(43^{\circ} 05^{\prime} \mathrm{N}, 77^{\circ} 05^{\prime} \mathrm{E}\right.$; Fig. 1) was the largest one in the 11 glaciers. The surface area was $2.4 \mathrm{~km}^{2}$; the length was $2.8 \mathrm{~km}$; and the volume was about $1 \times 10^{8}$ $\mathrm{m}^{3}$ (Makarevich and Kasatkin, 2008). The highest point of the glacier was at $4,219 \mathrm{~m}$ asl while the terminus was at the altitude around $3,500 \mathrm{~m}$ asl. The average elevation of the surrounding ranges was $4,200 \mathrm{~m}$ asl.

\section{Data and methods}

\subsection{Data}

The initial data include materials of all-year-round observations carried out by the Institute of Geography of the Republic of Kazakhstan at the Tuyuksu Glacier station (TGS; 3,450 m asl; Fig. 1) in the Little Almatinka valley since 1957.

Mass balance measurements were started from 1956 by a stake network along longitudinal profiles and cross-sections on Tuyuksu. The observations of accumulation and ablation on the glacier were conducted several times a year based on a combination of fixed-date with stratigraphic system method for 120 stakes and snow pits in the accumulation and the ablation areas on the glacier. The point measurements were then used to estimate the annual, winter and summer mass balances or seasonal and annual equilibrium line altitudes in each year based on an isopleth or altitudinal 


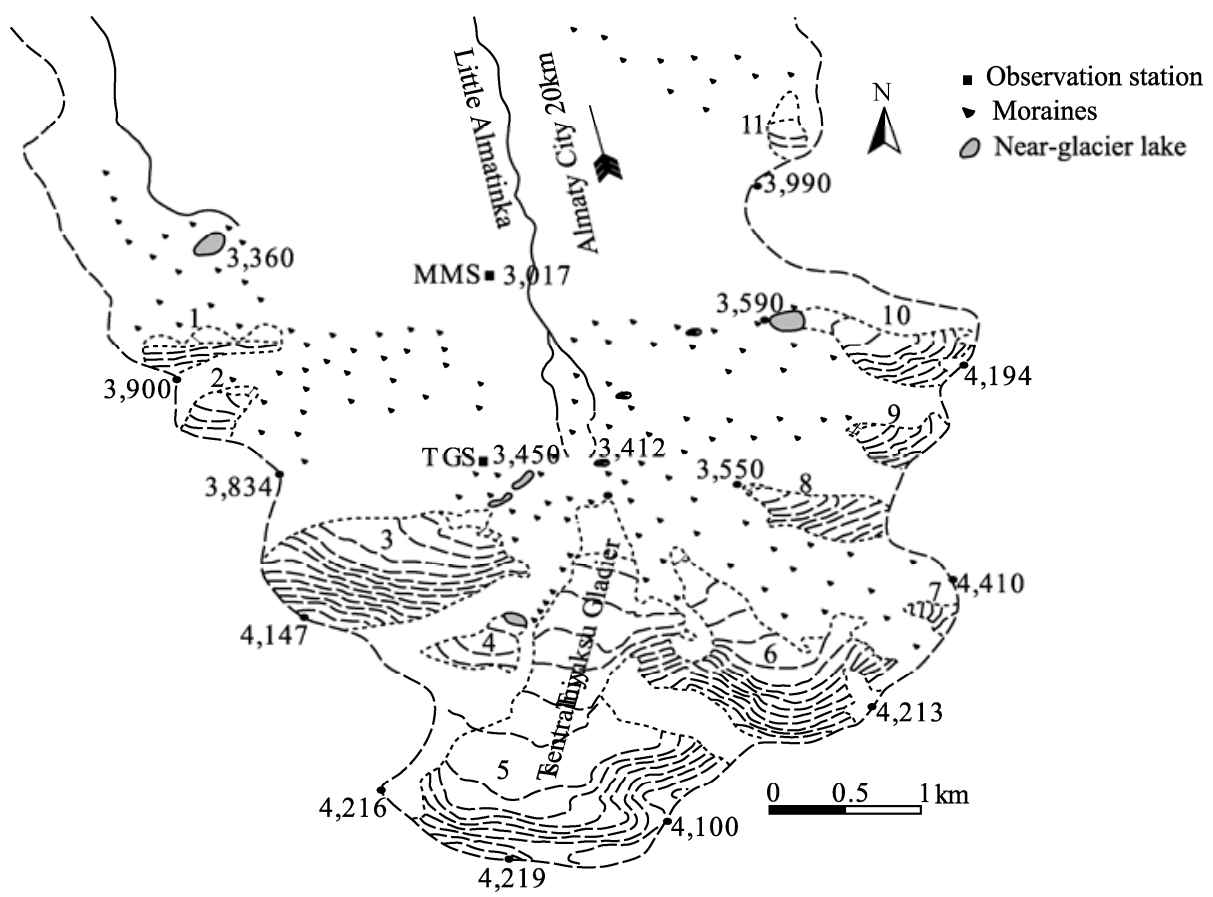

Fig. 1 Sketch map of the upper reaches of the Little Almatinka River and the observation sites of the Mynzhilki Meteorological Station (MMS) and Tuyuksu Glaciological Station (TGS). Glaciers: 1, Titov; 2, Visyachiy; 3, Molodezhniy; 4, Zoya Kosmodemyanskaya; 5, Central Tuyuksu; 6, Igly Tuyuksu; 7, Partisan; 8, Ordjonikidze; 9, Mayakovskiy; 10, Manshuk Mametova; 11, Abai.

band mean of mass balance method. Glaciers of the Zailiyskiy Alatau range have been in retreat since decades ago (Bolch, 2007; Makarevich and Kasatkin, 2008; Narama et al., 2010). According to the observation data since 1956 the Tuyuksu Glacier retreated by $750 \mathrm{~m}$ with a rate of $13.6 \mathrm{~m} / \mathrm{a}$, which was confirmed by the negative mass balances of the glacier. Measurements showed an accumulated mass loss of $22.24 \mathrm{~m}$ of water equivalent happened in the period from 1957 to 2012 , of which about $96 \%$ of the mass loss occurred in 1971-2012. That was the reason why we selected 1971-2012 as the study period. Figure 2 presented the relationships among the fluctuation of the annual mass balance, the equilibrium line altitude (ELA) of the glacier and the summer temperature.

Precipitation at TGS was manually measured during the study period. The forms of precipitation, solid, liquid and solid-liquid mixture, were identified in-situ. The amount of solid and liquid precipitation was separately measured with the weight method. During the summertime of the study period, solid precipitation happened when the temperature was below $2.8^{\circ} \mathrm{C}$; precipitation was in solid-liquid mixed form when the temperature was between $2.8-4.2^{\circ} \mathrm{C}$; liquid precipita- tion appeared when the temperature was above $4.2^{\circ} \mathrm{C}$. The precipitation in solid form decreased and the precipitation in solid-liquid mixed form slightly increased since 1971 but with an obvious decadal variables. The amount and the form of the precipitation falling on the glacier have significant effects on the mass balance dynamics.

\subsection{The classification of circulation types}

Linkages between glacier mass balances and largescale atmospheric circulation anomalies were discussed in the study by Eriskovskaya and Pimankina (2009), in which some teleconnection patterns were identified. As the Northern Hemisphere climatic variability may be predictable based on the teleconnections and this provides the potential for predicting glacier mass balances up to several years in advance. The inter-annual variables of ablation and accumulation of the Djankuat Glacier in Caucasus Mountains, Russian, was found associated with the climate variability in the Northern Hemisphere (Shahgedanova et al., 2005).

The climate in the study area was controlled by 4 types of weather regimes: 1) cyclones with warm tropical air masses from Iran and Afghanistan; 2) cold air from the north and the north-west; 3) anticyclones 

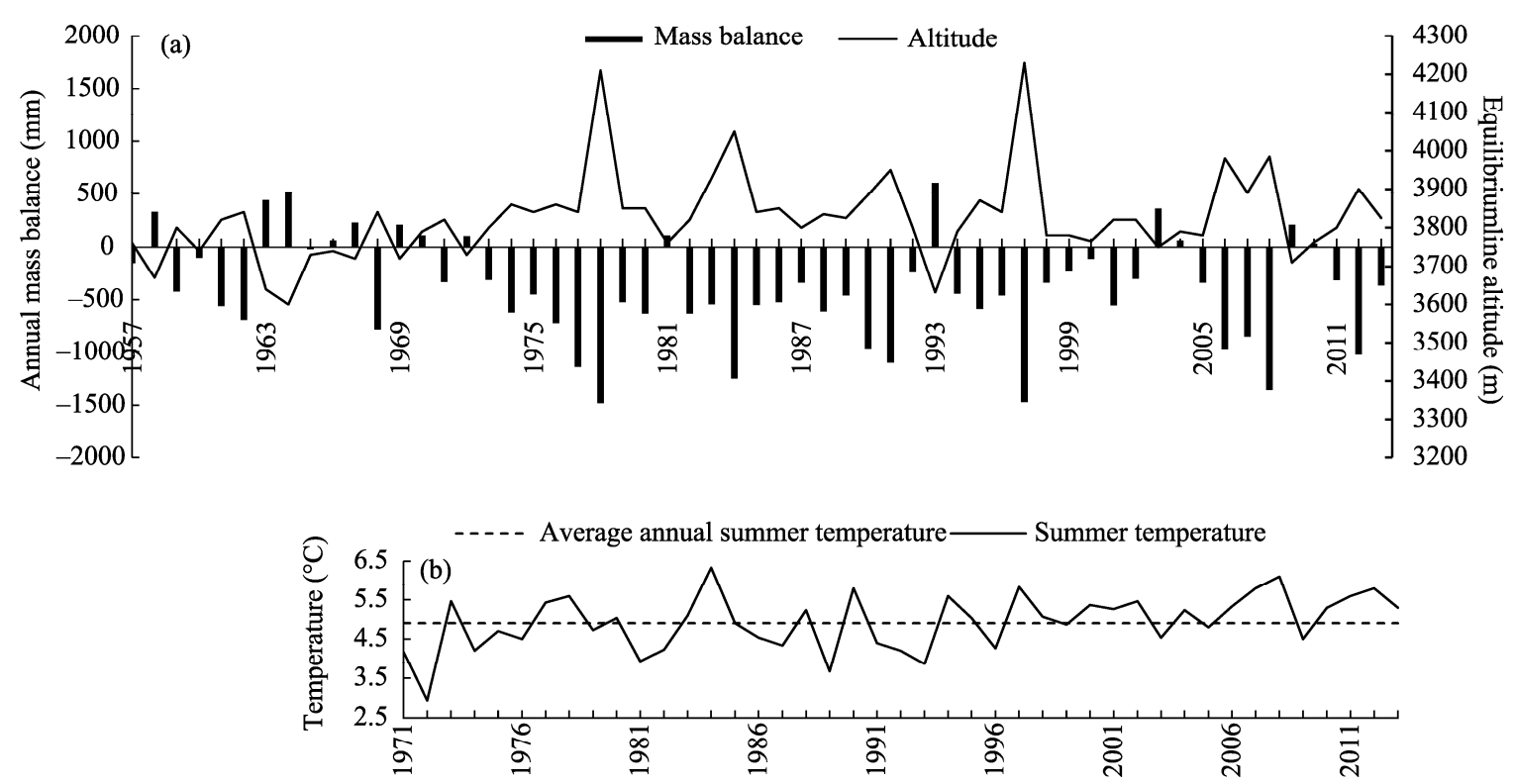

Fig. 2 Temperature, mass balance and equilibrium line altitude at Tuyuksu Glacier. (a) Temporal change of mass balance and equilibrium line altitude; (b) summertime temperature (June-August).

from the south-west and the south-east; 4) cold moisture-saturated air masses from the west. The region was under the effect of the cyclones and the anticyclones over the different periods during a year. Dzerdzeevskii (1962) identified and classified these circulation types by analyzing the trajectory of the cyclones and anticyclones in the Northern Hemisphere.

In this study, we used the Dzerdzeevskii's classification of atmospheric circulations, expressed as timing and lasting days, in extra-tropical latitudes of the Northern Hemisphere to analyze their relations with atmospheric precipitation falling in summer on the Tuyuksu Glacier. The basis, on which this classification was constructed, was the occurrence or absence of blocking processes, the direction and the frequency, i.e. the meridional and zonal components of the circulation. These were defined by Dzerdzeevskii (1962) to identify the corresponding directions of cyclone and anticyclone tracks reflecting the basic transfers-steering currents at the $700 \mathrm{mb}$ isobaric surface (and not infrequently at the $600 \mathrm{mb}$ surface). Processes with cyclonic circulation over the polar region were grouped into a separate unit. A series of daily isobaric charts were prepared based on aerial sounding measurements at different weather stations so that various circulation types and their dynamic tracks can be distinguished and the prevailing periods could be estimated. The circulation processes were classified into 4 groups of circulation types, which were further divided into 13 types and 41 sub-types according to the elementary circulation mechanisms (ECMs, data accessible at www.atmospheric-circulation.ru) (Table 1).

ECMs are presented in numbers (from 1 to 13 ) and letters. The number indicates the types of ECMs and the letter after a number stands for a sub-type, for example, a, b, v, or $g$ are attributed to geographical locations of blocking processes and southern cyclones outlets. The w or s after a number denotes winter or summer. ECMs are divided into 4 groups: zonal (without blocking processes), disturbance of zonal (with one blocking process), meridional northern (with 2-4 blocking processes) and meridional southern (without blocking processes and with cyclonic activity at the polar and three to four outlets of southern cyclones on the hemisphere) (Kononova, 2010). The number of days of ECMs during a year can be found in the calendar of ECMs alternation which made it possible to associate them with characteristics of weather regime. ECMs regulate the temperature and the moisture of air mass to influence the 
Table 1 Characteristics of the principal groups of the elementary circulation mechanisms (ECMs)

\begin{tabular}{|c|c|c|c|c|}
\hline Group & Type & $\begin{array}{l}\text { Atmospheric pres- } \\
\text { sure in Arctic }\end{array}$ & $\begin{array}{l}\text { The number of simultaneous blocking } \\
\text { processes in different sectors of hemisphere }\end{array}$ & $\begin{array}{l}\text { The number of simultaneous incursions of south- } \\
\text { ern cyclones in different sectors of hemisphere }\end{array}$ \\
\hline Zonal & 1,2 & High & 0 & $2-3$ \\
\hline Disturbance of zonality & $3-7$ & High & 1 & $1-3$ \\
\hline Meridional northern & $8-12$ & High & $2-4$ & $2-4$ \\
\hline Meridional southern & 13 & Low & 0 & $3-4$ \\
\hline
\end{tabular}

accumulation and the ablation of the glaciers.

To determine how large-scale circulation affects precipitation in the ablation period (June-August), we extracted the monthly and annual number of days of each circulation type and then summarized them in groups. The number of days with precipitation under different ECMs were calculated according to the daily dataset from TGS. The contribution of the ECMs to the precipitation in summer can be identified and the fluctuations of their frequency were analyzed. The values of meteorological parameters and glacier mass balances were calculated by using the "epochs of circulation", periods with notable prevalence of the definite circulation types (Dzerdzeevskii, 1962; Kononova, 2010; Matskovsky and Kononova, 2011).

\section{Results and discussion}

The effect of a specific type ECMs on the glacier summer mass balances was assessed according to the number of days under the different ECMs and the precipitation forms falling in June-August (Table 2). The average number of days with precipitation was 52 during June-August on the glacier. The mean annual precipitation for the studied period was $420 \mathrm{~mm}$, out of which $150 \mathrm{~mm}$ was in solid, $190 \mathrm{~mm}$ was in mixed-form and $80 \mathrm{~mm}$ was in liquid.

The main precipitation-bearing ECMs in the Zailiiskiy Alatau region were the summer sub-types of ECMs 2, 4, 9, 10 and 12. The sub-type 12a occurred mainly in the transition period of cold and warm. The days with greatest precipitation including intensive rainfalls $(>10 \mathrm{~mm} / \mathrm{d})$ were associated with the sub-type $13 \mathrm{~s}$, a prevailing cyclonic being active in the Arctic and the most part of the continent during 1972-2012. This ECM sub-type belonged to the meridional southern group of circulation and was

Table 2 The number of days with precipitation in June-August under different ECMs on the Tuyuksu Glacier (1972-2012)

\begin{tabular}{|c|c|c|c|c|c|c|c|}
\hline Group of ECMs & Type of ECMs & May & Jun & Jul & Aug & Sept & Total \\
\hline \multirow[t]{2}{*}{ Zonal } & $1 \mathrm{w}$ & 4 & 0 & 2 & 1 & 7 & 14 \\
\hline & $2 \mathrm{a}$ & 40 & 65 & 61 & 44 & 7 & 217 \\
\hline \multirow[t]{6}{*}{ Disturbance of zonal } & $3 \mathrm{~s}$ & 31 & 26 & 34 & 16 & 7 & 114 \\
\hline & $4 w+s$ & 50 & 62 & 73 & 50 & 17 & 252 \\
\hline & 5 & 0 & 0 & 4 & 10 & 10 & 24 \\
\hline & 6 & 10 & 38 & 18 & 19 & 10 & 95 \\
\hline & $7 \mathrm{~s}$ & 37 & 27 & 15 & 22 & 25 & 126 \\
\hline & $7 \mathrm{w}$ & 2 & 0 & 0 & 0 & 3 & 5 \\
\hline \multirow[t]{11}{*}{ Meridional northern } & $8 \mathrm{a}$ & 45 & 32 & 11 & 5 & 12 & 105 \\
\hline & $8 b$ & 25 & 15 & 20 & 13 & 9 & 82 \\
\hline & $8 \mathrm{c}$ & 13 & 12 & 14 & 10 & 22 & 71 \\
\hline & $8 \mathrm{~d}$ & 20 & 9 & 9 & 15 & 4 & 57 \\
\hline & 9 & 92 & 83 & 78 & 38 & 29 & 320 \\
\hline & 10 & 62 & 46 & 54 & 35 & 22 & 219 \\
\hline & 11 & 10 & 6 & 8 & 3 & 14 & 41 \\
\hline & $12 \mathrm{a}$ & 112 & 53 & 16 & 20 & 40 & 241 \\
\hline & $12 \mathrm{~d}$ & 14 & 0 & 0 & 1 & 11 & 26 \\
\hline & $12 \mathrm{bs}+\mathrm{cs}$ & 80 & 43 & 36 & 38 & 32 & 229 \\
\hline & $12 \mathrm{w}$ & 1 & 2 & 0 & 2 & 16 & 21 \\
\hline \multirow[t]{2}{*}{ Meridional southern } & $13 w$ & 5 & 0 & 0 & 1 & 51 & 57 \\
\hline & $13 \mathrm{~s}$ & 131 & 268 & 259 & 190 & 98 & 946 \\
\hline Total & & 784 & 787 & 712 & 533 & 446 & \\
\hline
\end{tabular}


frequently in active in summer. The location of the Tuyuksu Glacier was at the northwest periphery of an anti-cyclonic area under the control of ECM 13s and was adjacent to the tracks of Mediterranean cyclone.

It should be noted that the influence of ECMs in the studied area over a particular period depended on the position of a cyclone to the glacier. The form of the precipitation falling on the glacier surface also had a significant impact on the glacier accumulation and ablation. Intensive ablation might be the effect of the ECMs under the control of the anticyclones accompanied with relatively high temperature and low precipitation. When a cyclonic circulation prevailed over the region, the heavy clouds were developed, which resulted in a reduced solar radiation, lowered the air temperature and brought precipitation. The ablation would be reduced when the precipitation was in solid form due to the high albedo of the glacier surface which increased solar reflectance. The more the snowfall in the accumulation zone of the glacier, the weaker the negative mass balances would occur or even positive mass balances could happen.

Efforts was also devoted to estimate the contribution of individual ECM to the precipitation in various forms. A large number of days with solid and solidliquid mixed precipitation were observed under the ECM group, meridional northern (Table 3) while most liquid precipitation was brought by the ECM 13s.

We compared the period of each dominant circulation event (Dzerdzeevskii, 1962) with the decadal scale fluctuation of the glaciological and climatic characteristics of the glacier within the study period.

Table 3 The number of days and the form and the amount of precipitation falling during June to August, 1999-2012 under different ECMs on the Tuyuksu Glacier

\begin{tabular}{|c|c|c|c|c|c|c|c|}
\hline \multirow{2}{*}{ ECMs group } & \multirow{2}{*}{ ECMs type } & \multicolumn{2}{|c|}{ Solid precipitation } & \multicolumn{2}{|c|}{ Precipitation in mixed form } & \multicolumn{2}{|c|}{ Liquid precipitation } \\
\hline & & (d) & $(\mathrm{mm})$ & (d) & $(\mathrm{mm})$ & (d) & $(\mathrm{mm})$ \\
\hline Zonal & $2 \mathrm{a}$ & 3 & 26.5 & 2 & 30.3 & 7 & 20.1 \\
\hline Disturbance of zonal & 4 & 6 & 104.6 & 1 & 8.4 & 4 & 13.5 \\
\hline \multirow[t]{4}{*}{ Meridional northern } & $9 \mathrm{a}$ & 38 & 417.5 & 36 & 294.3 & 29 & 158.8 \\
\hline & $10 \mathrm{~b}$ & 12 & 52.7 & 10 & 176.8 & 9 & 20.0 \\
\hline & $12 \mathrm{a}$ & 41 & 327.7 & 30 & 399.1 & 17 & 120.1 \\
\hline & $12 \mathrm{bs}$ & 21 & 216.3 & 16 & 191.6 & 10 & 66.7 \\
\hline Meridional southern & $13 \mathrm{~s}$ & 66 & 653.1 & 76 & 699.1 & 74 & 405.9 \\
\hline
\end{tabular}

The analysis revealed that the time span of the fluctuation of glaciological parameters were associated with the large-scale circulation characteristics. We divided the study period into three periods which were under the influence of different ECMs.

The first period was from 1957 to 1973, during which the northern and southern meridional processes dominated the region (Table 4; Fig. 3). High accumulation in winter and weak negative annual mass balances were observed. The average altitude of equilibrium line was at $3,750 \mathrm{~m}$, which was lower than ELAs in the years under the dominance of the other circulation types (Yeriskovskaya and Pimankina, 2009). The dominant circulations in this period were the zonal and disturbed zonal processes.

The second period was from 1974 to 1998 , which was characterized by greater negative annual mass balances and a higher ELA at $3,870 \mathrm{~m}$ in average, which was $120 \mathrm{~m}$ higher than that in the first period (Fig. 3; Table 4). The dominant circulations were zonal processes (1974-1985) and meridional southern processes (1986-1998). Under the control of the zonal processes, the number of days with precipitation increased as well as the amount of precipitation (Figs. 5 and 6). However, the total precipitation was minimum during 1986-1998 under the control of the meridional southern processes (type 13s, pass of southern cyclones). The number of days with solid precipitation falling on the glacier reduced, which accompanied with a sharp increase (by 4 times) in the number of days with solid-liquid mixed and liquid precipitation as well as the amount of precipitation falling in these days. In general the variance of the mean monthly precipitation for the period (without 
examination of particular groups of circulation) was statistically insignificant. With Student's T-test, significant changes in precipitation was only found for February.

The third period was from 1999 to 2012, which was characterized by relatively favorable conditions for glacier ice accumulation. The period was associated with the development of the northern blocking pro- cesses, typically the meridional northern circulation group. During this period, the number of days under zonal processes reduced while the number of days under the meridonal processes increased in the Northern Hemisphere. The average precipitation during September to May next year was $10 \%$ higher than the long-term average annual precipitation in the 36 -year observation; the mean temperature in July was $6 \%$

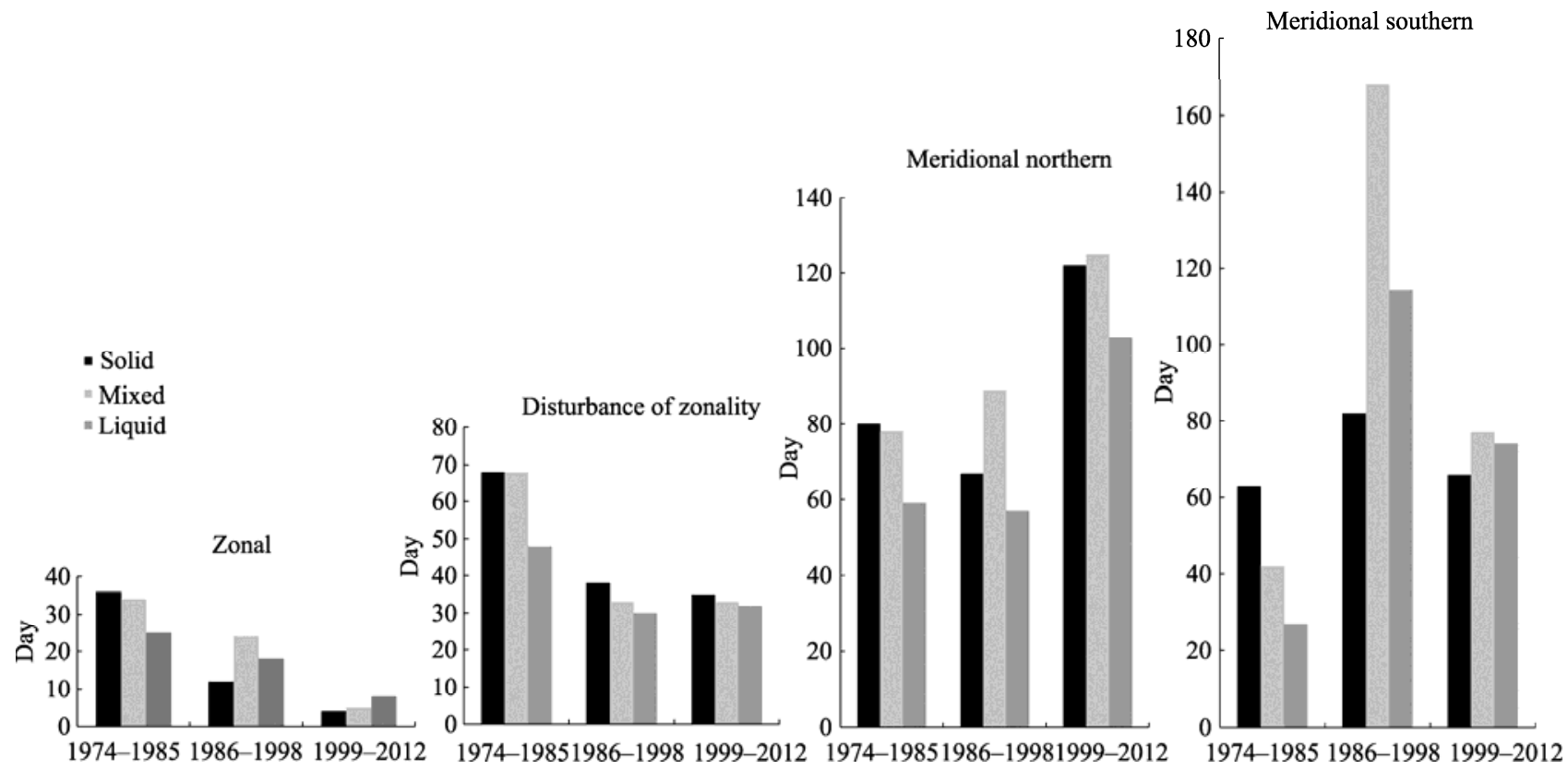

Fig. 3 Total days with precipitation falling on the Tuyuksu Glacier in June-August under atmospheric circulations of the various groups during three statistical periods of observations

Table 4 Climatic statistics of the Tuyuksu Glacier

\begin{tabular}{|c|c|c|c|c|}
\hline \multirow[b]{3}{*}{ Parameters at Tuyuksu Station or on the glacier } & \multicolumn{4}{|c|}{ Observation period } \\
\hline & \multirow[b]{2}{*}{$\begin{array}{l}\text { 1957-1973 (Meridi- } \\
\text { onal north and } \\
\text { southern processes) }\end{array}$} & \multicolumn{2}{|c|}{ 1974-1998 } & \multirow[b]{2}{*}{$\begin{array}{l}\text { 1999-2012 (Me- } \\
\text { ridional north } \\
\text { processes pre- } \\
\text { vailing) }\end{array}$} \\
\hline & & $\begin{array}{c}\text { 1974-1985 } \\
\text { (Zonal processes } \\
\text { prevailing) }\end{array}$ & $\begin{array}{c}1986-1998 \\
\text { (Meridional south } \\
\text { processes prevailing) }\end{array}$ & \\
\hline Average air temperature for September-May $\left({ }^{\circ} \mathrm{C}\right)$ & $-7.3^{*}$ & -7.1 & -6.8 & -6.2 \\
\hline Average air temperature for June-August $\left({ }^{\circ} \mathrm{C}\right)$ & $4.1^{*}$ & 4.9 & 4.8 & 5.3 \\
\hline Average air temperature in July $\left({ }^{\circ} \mathrm{C}\right)$ & $4.6^{*}$ & 5.9 & 5.7 & 5.7 \\
\hline Sum of precipitation for September-May at Tuyuksu-1 (mm) & $563^{*}$ & 549 & 535 & 670 \\
\hline Sum of precipitation for June-August (mm) & $445^{*}$ & 385 & 446 & 422 \\
\hline Average snow depth in April (cm) & - & 67 & 84 & 108 \\
\hline Winter balance (mm) & 1,086 & 555 & 500 & 637 \\
\hline Summer balance $(\mathrm{mm})$ & $-1,186$ & $-1,257$ & $-1,030$ & -969 \\
\hline Annual balance (mm) & -100 & -702 & -530 & -332 \\
\hline Equilibrium line altitude (m) & 3,750 & 3,892 & 3,852 & 3,817 \\
\hline
\end{tabular}

Note: Data in brackets were reconstructed using data from the Mynzhilki Meteorological Station (H, 3,017 $\mathrm{m}$ asl), located 3 km northward from the Tuyuksu-1. Data on the mass balance are taken from Makarevich (2008). 


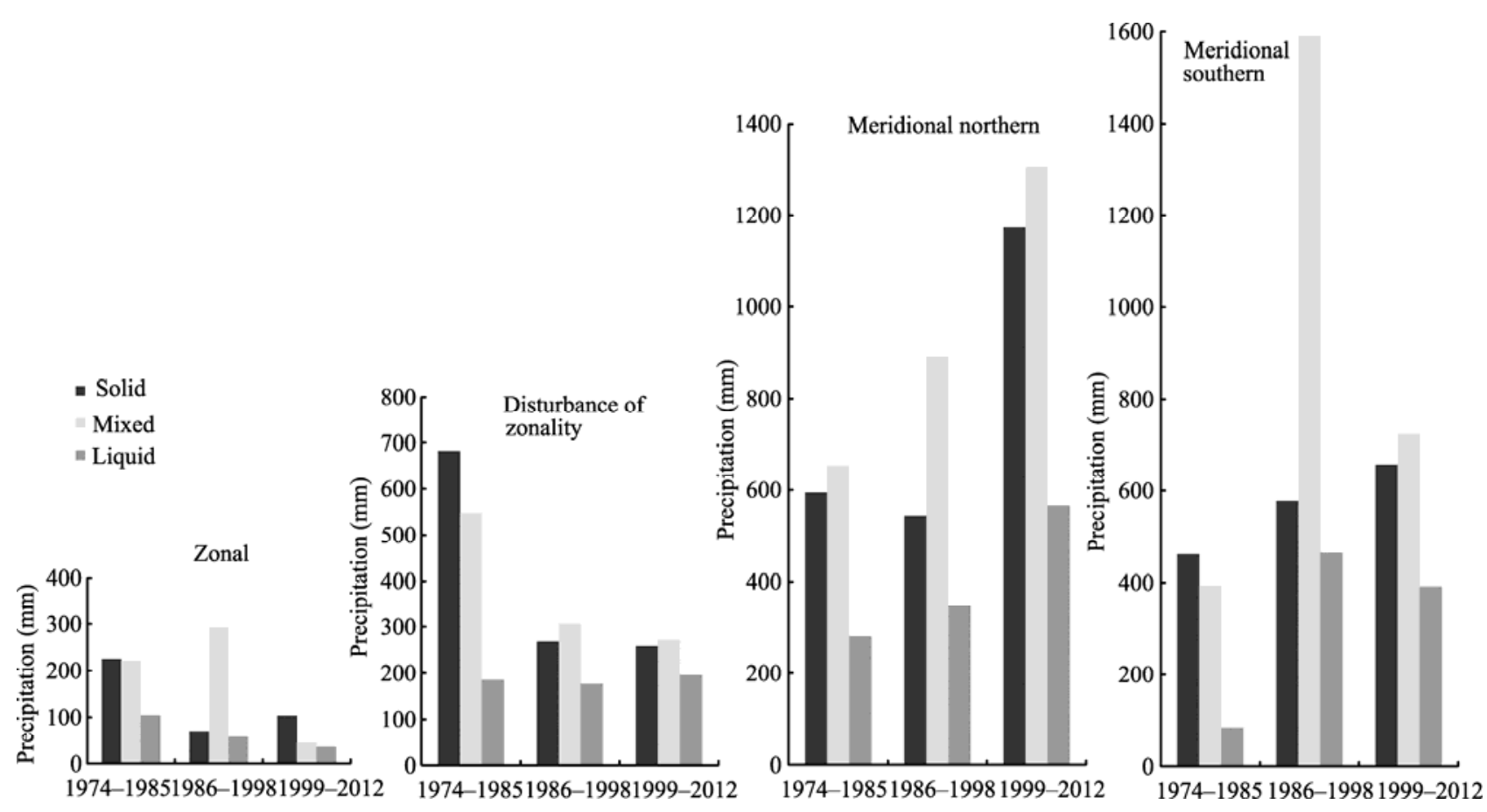

Fig. 4 Different forms of precipitation (solid, mix, liquid) falling on the Tuyuksu Glacier in June-August according to the groups of atmospheric circulation during different periods of observation

lower than the long-term average.

Cyclones moving from the Eastern Mediterranean to the Asian continent encountered a barrier, the blocking anticyclone over the European part of Russia (Volga region, and Siberia) along its track. Atlantic cyclones bypassed European anticyclones from the north, cyclone trajectories were then changed. The region of the Tuyuksu Glacier was either under the influence of southern cyclones or was in a zone of the convergence of the Mediterranean cyclones bypassing the south spur of the Azores anticyclone, along with Atlantic cyclones approaching here from the northwest (Kononova, 2010). The number of precipitation days under these processes during 1999-2012 increased by $60 \%$ compared to the previous decade and the total solid precipitation falling in June-August was $17 \%$ higher than the long-term average (Kononova et al., 2014). However, the average summer temperature was stabilized at a rather high level in this period (Fig. 2). ELA did not fall below $3,700 \mathrm{~m}$ asl and rose to almost 4,000 $\mathrm{m}$ asl in the summers of 2006 and 2008. The Tuyuksu Glacier was in the negative mass balances. The increased solid precipitation could not fully compensate the increased ablation due to global warming.

The meridional northern circulation provided the most favorable conditions for the mass gain of glaciers in the region due to the increased precipitation in the cold period. Frequent and plentiful precipitation (most in solid or mixed form) during ablation season could also significantly reduce the length of ablation period and the intensity of ablation which leaded to weak negative summer balance. The more precipitation in non-liquid form under the interaction of circulation systems either in cold seasons or warm seasons can benefit glacier ice accumulation due to the increased albedo on the glacier surface.

\section{Conclusion}

The findings of our study were preliminary. But it allowed us to explore the relationship between the large-scale circulation patterns and the glacier mass balances in the Zailiiskiy Alatau region. The basic findings were that regional circulation patterns controlled the temperature, the precipitation, the fluctuations of ELAs and the mass balances. Most of the precipitation in the Tuyuksu Glacier area during June-August was formed under meridional southern and northern circulation processes according to Dzerdzeevskii's classification. The meridional northern group of circulations were dominant processes which 
controlled the fluctuations of ELA and the glacier mass balances. The increase in the duration of meridional northern circulations had a positive correlation with the number of days with precipitation and the sum of solid precipitation in June-August at the glacier zone. This suggested that the intensive melt on the Tuyuksu Glacier could have been retarded due to plentiful solid precipitation although the regional warming was obvious at the same time.

The prevalence of the meridional processes of the atmospheric circulations over the Northern Hemisphere may lead to the formation of the blocking anticyclones and an increase in the number of cyclones over the region. Such a pattern brings about increased precipitation and an increased portion of precipitation in solid form falling on the glaciers. Considering the length of previous periods of total annual duration of blocking processes in the Northern Hemisphere, it can be inferred that this situation will continue until at least 2030. More snowfall during the summer time can greatly increase the albedo and therefore reduce the surface ablation which could result in a weakened negative or even positive mass balances in the region.

\section{Acknowledgements}

This work was funded by International Science \& Technology Cooperation Program of China (2010DFA92720-23, 2012BAC19B07), Knowledge Innovation Project of the Chinese Academy of Sciences (KZCX2-YW-GJ04) and carried out by the Institute of Geography, Republic of Kazakhstan with the support from the Ministry of Education and Science of Kazakhstan.

\section{References}

Baidal M H. 1964. Long-term weather forecasts and climate fluctuations in Kazakhstan. Leningrad Gidrometeoizdat, 446. (In Russian)

Bolch T. 2007. Climate change and glacier retreat in northern Tien Shan (Kazakhstan/Kyrgyzstan) using remote sensing data. Global and Planetary Change, 56: 1-12

Cherkasov P A, Yeliskovskaya L A. 1997. Phase and composition of warm season precipitation in the glacier areas in Alto Mountains. In: The effects of human activities on water resources and environment in Central Asia and evaluation of snow resources on Tianshan mountains. Urumqi, China, 215-223. (in Chinese)

Denisova T Ya, Makarevich K G, Panova E N, et al. 1986. The influence of macro-scale atmospheric processes on the fluctuations of glaciers.Data of Glaciological Studies, 57: 52-58. (in Russian)
Dzerdzeevskii B. 1962. Fluctuations of climate and of general circulaionof the atmosphere in extra-tropical latitudes of the Northern Hemisphere and some problems of dynamic climatology. Tellus A, 14(3): 328-336.

Girs A A. 1974. Macro-circulation method of long-term meteorological forecasts. Leningrad Gidrometeoizdat, 488. (In Russian)

Golovkova R G, Denisova T Y, Tokmagambetov G A. 1986. The influence of atmospheric circulation onto the energy balance and ablation of the Tuyuksu Glacier. Data of Glaciological Studies, 58: 29-34.

Hagg W, Braun L N, Kuhn M, et al. 2007. Modelling of hydrological response to climate change in glacierized Central Asian catchments. Journal of Hydrology, 332: 40-53.

Kononova N K. 2010. Long-term fluctuations of the Northern Hemisphere atmospheric circulation according to Dzerdzeevskii's classification. Geography, Environment, Sustainability, 1(3): 25-43.

Kononova N K, Pimankina N V, Yeriskovskaya L A. 2014. The Influence of Modern Climate Fluctuations on the Conditions of the Tuyuksu Glacier. In: The Influence of Climate Changes on Snow, Ice and Water Resources, Bishkek, Kyrghyzstan, 52-53.

Makarevich K G, Kasatkin N E. 2008. 50 years of the studies of the balance of masses of the Central Tuyuksu Glacier in the Zailiiskiy Alatau. In: Medeu A. Geographical Problems Of Sustainable Development: Theory And Practice. Almaty: Print-S, 99-111. (in Russian)

Matskovsky V V, Kononova N K. 2011. Research of fluctuations of the northern hemisphere atmospheric circulation by the method digital mapping. Izvestiya Akademii Nauk Seriya Geograficheskaya, 6: 100-114. (in Russian)

Narama C, Kaab A, Duishonakunov M, et al. 2010. Spatial variability of recent glacier area changes in the Tien Shan Mountains, Central Asia, using Corona (similar to 1970), Landsat (similar to 2000), and ALOS (similar to 2007) satellite data. Global and Planetary Change, 71: 42-54.

Shahgedanova M, Stokes C R, Gurney S D, et al. 2005. Interactions between mass balance, atmospheric circulation, and recent climate change on the Djankuat Glacier, Caucasus Mountains, Russia. Journal of Geophysical Research-Atmospheres, 110(D4), doi: 10.1029/2004JD005213.

Pimankina N, Kononova N K, Yeriskovskaya L A. 2013. Analysis of the influence of atmospheric circulation onto the fluctuations of the Tuyuksu Glacier mass balance (Ile Alatau mountains). //Abstract Proceedings of Davos Atmosphere and Cryosphere Assembly DACA-13. July 8-12, 2013. P. 1116.

Vangengeim G Y. 1952. Principles of macro-circulation method of long-term meteorological forecast for the Arctic, In: Proceedings of the Arctic Research Institute. Leningrad Gidrometeoizdat, 34: 312. (In Russian)

Yeriskovskaya L, Pimankina N. 2009. Climate fluctuations and mass-balance of the tuyuksu glacier (Ile Alatau). Hydrometeorology and Ecology, 3: 78-84.

Yeriskovskaya L A. 2003. The influence of climatic changes onto the glaciation in alpine zone of the Zailiiskiy Alatau Range (case study of the Tuyuksu Glacier). Hydrometeorology and Ecology, 4: 31-34. 